\title{
How are flood risk estimates affected by the choice of return-periods?
}

\author{
P. J. Ward ${ }^{1,2}$, H. de Moel ${ }^{1,2}$, and J. C. J. H. Aerts ${ }^{1,2}$ \\ ${ }^{1}$ Institute for Environmental Studies (IVM), VU University Amsterdam, Amsterdam, The Netherlands \\ ${ }^{2}$ Amsterdam Global Change Institute (AGCI), VU University Amsterdam, Amsterdam, The Netherlands
}

Received: 8 July 2011 - Revised: 27 September 2011 - Accepted: 26 October 2011 - Published: 7 December 2011

\begin{abstract}
Flood management is more and more adopting a risk based approach, whereby flood risk is the product of the probability and consequences of flooding. One of the most common approaches in flood risk assessment is to estimate the damage that would occur for floods of several exceedance probabilities (or return periods), to plot these on an exceedance probability-loss curve (risk curve) and to estimate risk as the area under the curve. However, there is little insight into how the selection of the return-periods (which ones and how many) used to calculate risk actually affects the final risk calculation. To gain such insights, we developed and validated an inundation model capable of rapidly simulating inundation extent and depth, and dynamically coupled this to an existing damage model. The method was applied to a section of the River Meuse in the southeast of the Netherlands. Firstly, we estimated risk based on a risk curve using yearly return periods from 2 to $10000 \mathrm{yr}$ ( $€ 34$ million p.a.). We found that the overall risk is greatly affected by the number of return periods used to construct the risk curve, with over-estimations of annual risk between $33 \%$ and $100 \%$ when only three return periods are used. In addition, binary assumptions on dike failure can have a large effect (a factor two difference) on risk estimates. Also, the minimum and maximum return period considered in the curve affects the risk estimate considerably. The results suggest that more research is needed to develop relatively simple inundation models that can be used to produce large numbers of inundation maps, complementary to more complex 2-D-3-D hydrodynamic models. It also suggests that research into flood risk could benefit by paying more attention to the damage caused by relatively high probability floods.
\end{abstract}

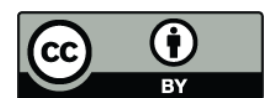

Correspondence to: P. J. Ward (philip.ward@ivm.vu.nl)

\section{Introduction}

Traditionally, flood management has concentrated on providing protection against floods through technical measures aimed at reducing the probability of a flood occurring (e.g. Vis et al., 2003; Merz et al., 2010a). However, international water management is increasingly shifting towards a more integrated system of flood risk management (Few, 2003; Tunstall et al., 2004; Merz et al., 2010a), whereby flood risk is defined as the probability of flooding multiplied by the potential consequences (Kron, 2005; Samuels and Gouldby, 2005). This move from traditional flood management to flood risk management can be seen at several scales, ranging from international to local. For example, in Europe flood risk management has been given added impetus by the European Flood Directive (EFD) (Directive 2007/60/EC), which requires Member States to assess whether water courses and coastlines are at risk from flooding, to map the flood extent of different events and to apply measures to reduce flood risk.

In economic terms, flood risk is often expressed in terms of expected annual damage. In order to calculate the expected damage for a given flood event, the most common approach involves combining data on the characteristics of the event (hazard) with information on the assets that would be affected by it (exposure) and information about the susceptibility of those exposed assets to the particular hazard (e.g. De Moel and Aerts, 2011; Kron, 2005; Merz et al., 2010a). In these studies, hazard is represented by hazard-maps, showing certain flood characteristics related to a particular flood, for example, inundation depth, flow velocity, inundation duration and sediment or contamination load. The most commonly used flood hazard characteristic is inundation depth (e.g. Penning-Rowsell et al., 1994; Wind et al., 1999). Exposure is often represented by land use maps, whereby each land use class is assigned an economic value per hectare (Merz et al., 2007; Meyer et al., 2009). Finally, susceptibility is most commonly represented by so-called stage-damage

Published by Copernicus Publications on behalf of the European Geosciences Union. 
functions (SDFs), which show the amount of damage that would occur per hectare for each land use class and for different values of the flood hazard (e.g. Merz et al., 2007).

In order to derive risk estimates, the calculated flood damages are combined with information on the probability of such events and then plotted as an exceedance probabilityloss (risk) curve, whereby the risk is approximated by the area under the curve (Meyer et al., 2009). In practice, pragmatic considerations of time and resource availability dictate the number of data points used to develop such a risk curve. For example, Merz and Thieken (2009) used seven return periods to produce risk curves for Cologne, Germany, which is relatively many data points compared to most other studies. There is, however, little insight into how the selection of the return-periods (which ones and how many) used to create the risk curve actually affects the final risk calculation. The only studies known to us that provide guidance in this regards are those by Messner et al. (2007) - which states that at least three and preferably six flood return periods should be used - and the Multi-Coloured Handbook (Penning-Rowsell et al., 2010) - which recommends using at least five floods. However, a strong scientific basis for such guidance is lacking due to the lack of research specific to this point.

In an ideal situation, estimating risk through the integration of risk curves would involve the simulation of inundation maps for hundreds to thousands of return periods. However, the production of flood hazard maps is generally time-consuming and computationally expensive (Gouldby and Kingston, 2007; Apel et al., 2008). There is currently a large range of models that can be used to develop flood hazard maps, ranging from zero-dimensional planar models to three-dimensional solutions of the Reynolds averaged Navier-Stokes equations. Even relatively simple 1-D and coupled 1-D-2-D models run on the order of minutes to hours for river-stretches of the order of magnitude 10$100 \mathrm{~km}$, whilst full 2-D or 3-D models may even take several days (e.g. Woodhead et al., 2007).

In this paper, we examine how flood risk estimates are affected by the selection of return-periods (which ones and how many) used to estimate the risk. In order to achieve this, we develop and validate an inundation model capable of rapidly simulating inundation extent and depth, and dynamically couple this to an existing damage model. The method is applied to a section of the River Meuse in the southeast of the Netherlands.

\section{Study area and past studies}

We carried out the research for the section of the River Meuse flowing through the Dutch province of Limburg, in the southeast of the Netherlands (Fig. 1). We selected this case study area for a number of reasons. Firstly, relatively good data are available for setting up both the inundation and damage models. Secondly, whilst the area is relatively prone to flooding in comparison to the downstream sections of the Meuse (as safety standards are considerably lower), it has received much less attention than the latter in major recent studies on flood risk in the Netherlands (e.g. Aerts et al., 2008; Klijn et al., 2007; Ministry of Transport, Public Works and Water Management, 2005).

\subsection{Study area: River Meuse in Dutch Limburg}

The Meuse is a predominantly rain-fed river with a length of ca. $875 \mathrm{~km}$ from its source in France to its outlet in the Netherlands. The catchment extends over parts of Belgium, France, Germany, Luxembourg and the Netherlands, and has an area of ca. $33000 \mathrm{~km}^{2}$. Mean annual precipitation over the basin is ca. $950 \mathrm{~mm} \mathrm{a}^{-1}$ and is reasonably evenly distributed throughout the year. The mean annual discharge of the Meuse and its associated canals at the border of Belgium and the Netherlands is ca. $276 \mathrm{~m}^{3} \mathrm{~s}^{-1}$ (Ashagrie et al., 2006). The Meuse has a relatively rapid response to rainfall, so it is relatively sensitive to floods (Van Pelt et al., 2009); flood waves mainly occur during the winter half-year.

The section of the Meuse studied in this research flows between the border of Belgium and the Netherlands (upstream) to river kilometre 166 (downstream) (Mook; see Fig. 1). Along part of the southern section of this stretch, the Meuse forms a natural border between Belgium and the Netherlands. Hence, during floods the river can flood on both the Dutch and the Belgian side. In this study, we have only examined inundation in the Netherlands. The Limburg Meuse occupies a terraced river valley (Van der Meulen et al., 2006); unembanked sections can be inundated as river levels rise above bankfull. There are also several (relatively small) dikering areas along this stretch of the Meuse; the safety standard for theses small dike-rings corresponds to a return period of $250 \mathrm{yr}$.

\subsection{Past studies: climate, hydrology, and risk}

Since the floods of 1993 and 1995, considerable research has been carried out to examine the past and future climatology of the Meuse basin and the hydrological response of the Meuse river (e.g. Aerts et al., 2006; Booij, 2005; Bultot et al., 1988, 1990; De Wit et al., 2001, 2007; Gellens, 1991; Gellens and Roulin, 1998; Giorgi and Coppola, 2007; Kwadijk and Rotmans, 1995; Leander et al., 2008; Middelkoop et al., 2004; Pfister et al., 2000; Tu, 2006; Van den Hurk et al., 2007; Van Deursen and Middelkoop, 2002; Vanneuville and Holvoet, 2009; Van Pelt et al., 2009; Ward et al., 2007, 2008, 2011). Although there are differences in the results, most studies suggest that the frequency of floods will increase in the future due to climate change. Several studies of the Meuse have looked specifically at the effects of changes in land use on the hydrology of the Meuse, finding: (a) a relatively small influence of changes in land cover during the 20th century (Ashagrie et al., 2006; Tu et al., 2005; Te Linde 


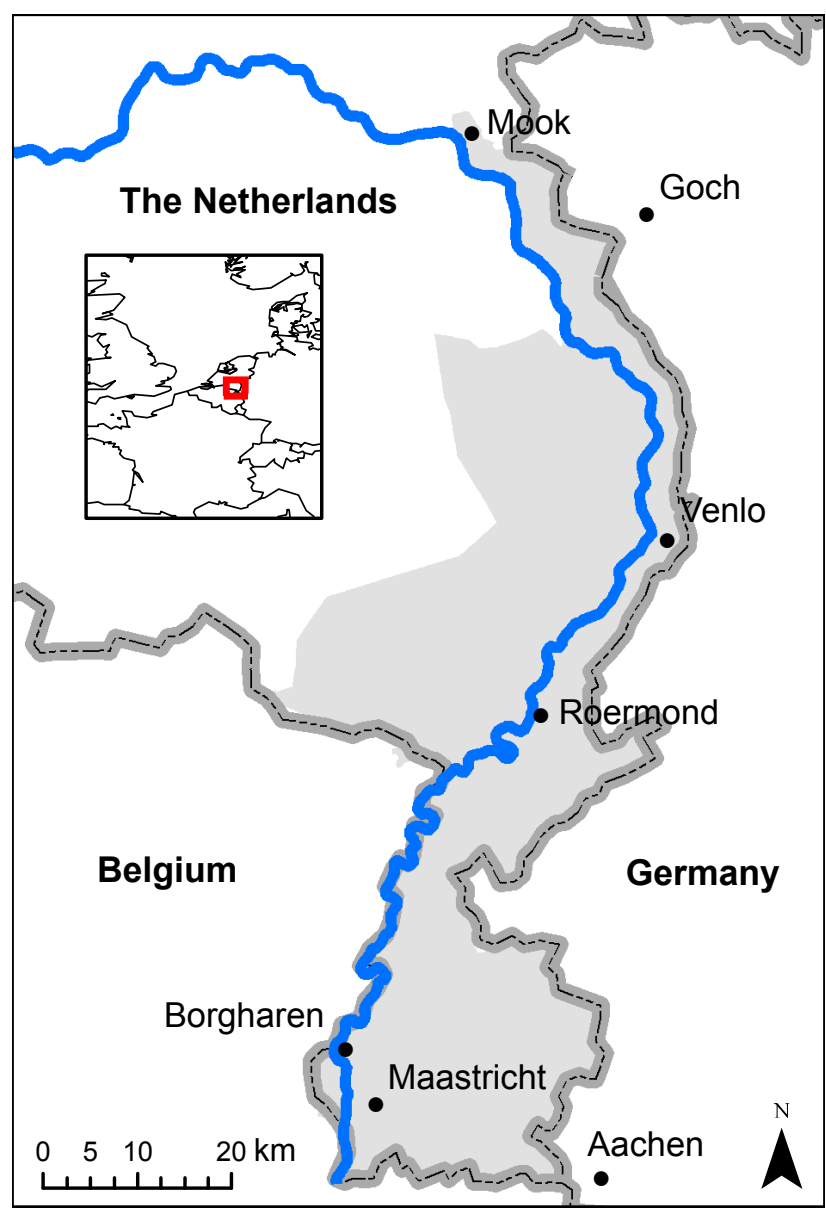

Fig. 1. Map showing the location of the study area. Dutch Limburg is shown in grey: the river Meuse enters The Netherlands in the south from Belgium and drains into the North Sea to the west of Rotterdam.

et al., 2007; Ward et al., 2008, 2011); (b) a larger influence of the way the land was managed during the 20th century (Fenicia et al., 2009); and (c) a large influence of land use change over the last $4000 \mathrm{yr}$ (Ward et al., 2008, 2011).

Risk estimates have been made for large Dutch dike ring areas downstream from Mook (Fig. 1) in several major projects: Floris (Ministry of Transport, Public Works and Water Management, 2005); Nederland Later (Klijn et al., 2007); and Attention to Safety (Aerts et al., 2008). Other recent publications that investigated flood risk in those large downstream dike rings are De Moel et al. (2011), who examined how flood exposure has changed in the Netherlands since 1900 and Bouwer et al. (2009, 2010), who estimated future potential damage from river flooding in dike-ring 36 (Land van Heusden/De Maaskant).

Far fewer studies have examined the upstream area of the Meuse from river kilometre 166. Ernst et al. (2010) assessed high-resolution economic damage $(2 \mathrm{~m} \times 2 \mathrm{~m})$ along two stretches of the river Ourthe, a tributary of the Meuse in Belgium. Wind et al. (1999) report on observed damages in Dutch Limburg following the flood events of 1993 and 1995, based on damage assessments commissioned by the Dutch government. These suggest total (direct) damage of ca. $€ 149$ million (1993) and $€ 91$ million (1995) ${ }^{1}$ (in year 2000 Euros). Van der Sande et al. (2003) simulated direct damages in the villages of Itteren and Borgharen (in Dutch Limburg) as a result of the 1995 floods using the LISFLOOD-FP flood simulation model (Bates and De Roo, 2000), land cover maps from IKONOS-2 imagery and relations between water depth and property damage. Their simulations yield estimated property damages of ca. $€ 82$ million (in year 2000 euros).

\section{Methods}

An overview of the methods and modelling chain used is shown in Fig. 2. Two models are dynamically coupled: a flood inundation model and a flood damage model. The first model, Floodscanner, was developed for this research, to simulate inundation depths for given values of discharge at the upstream part of the river. Input to the model are: discharge rating-curves showing the relationship between river discharge and water level (stage) at each river kilometre; estimates of discharge $(Q)$ for different return-periods (ranging from 2 to $10000 \mathrm{yr}$ ); and a Digital Elevation Model (DEM). The outputs of the model are inundation maps showing flood extent and depth per grid-cell for each discharge input value. These maps were then used as input to an existing flood damage model (Damagescanner), together with a land use map (Aerts et al., 2008; Klijn et al., 2007). The outputs of this model are maps showing the potential damage per grid-cell for each discharge input value. By calculating the damage over the river stretch for different return-periods (2 to $10000 \mathrm{yr}$ ), we then calculated flood risk (expected annual damage in Euros) by approximating the area under the risk curve. Each of the methodological steps is described in more detail in this section.

\subsection{Inundation modelling: Floodscanner}

For most official studies, inundation maps of the Meuse in Dutch Limburg are derived using the 2-D hydrodynamic model, WAQUA. However, WAQUA is a complex model requiring considerable computing time to generate inundation characteristics for a single flood event. As the aim of this study is to examine how flood risk estimates are affected by the selection of return-periods, thousands of inundation maps are required. We have, therefore, developed a new model, Floodscanner. We used the most simple zero-dimensional

\footnotetext{
1 The original values (in Dutch Guilders) were converted to Euros (1 Euro = 2.20371 Dutch Guilders), and then updated from 1993 and 1995 values to 2000 values, using GDP multipliers derived from Statistics Netherlands (www.cbs.nl)
} 


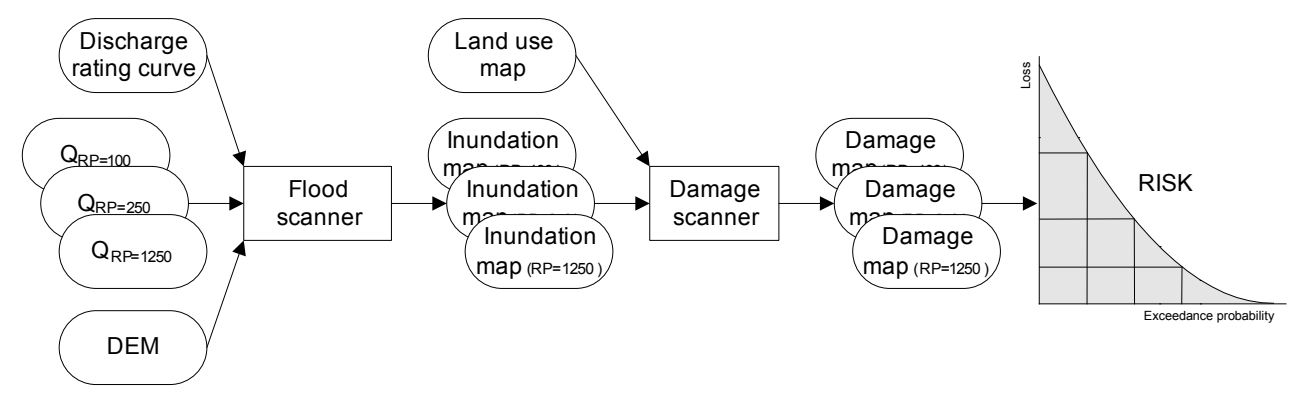

Fig. 2. Overview of the methods used in the study. Floodscanner is a model developed for this research that produces maps of inundation depth per grid-cell. Damagescanner (Aerts et al., 2008; Klijn et al., 2007) estimates the economic damage per grid-cell. Risk, in terms of expected annual damage, is calculated by approximating the area under the resulting exceedance probability-loss curve.

planar-based approach, similar to that described in Priestnall et al. (2000) and validated this against results from aerial photography and WAQUA modelling (Sect. 4.1.1).

The model is raster-based, with a spatial resolution of $50 \mathrm{~m} \times 50 \mathrm{~m}$. In brief, the method involves using stagedischarge relationships to estimate the water level at each river grid-cell for different discharges. These water levels are then assigned to the nearest non-river grid-cells, essentially creating a planar surface representing the water level per grid-cell. This planar water level is then intersected with a Digital Elevation Model (DEM), and the inundation depth is the difference between the cell values of water level and elevation. Several modifications are made to this classic approach, namely: we used an algorithm to remove flooded cells that are not connected to the river via a logical flow path, and we added a module to prevent flooding occurring in the small dike-ring areas along the Meuse when the discharge is below the design discharge of that dike-ring. Several steps are required to carry out the simulation: (a) derive river network raster; (b) develop stage-discharge relationships; (c) simulate planar water-level surface; and (d) estimate flood inundation depth. These steps, and the data sources used in this study, are described in the following paragraphs.

\subsection{Derive river network raster}

We developed the river network raster based on a DEM derived from elevation data used in the WAQUA model of the Meuse. These data were provided by Rijkswaterstaat Limburg (RWS Limburg), as a Triangulated Irregular Network (TIN) map. We used the TIN file for WAQUA-version 2005-02, configuration J09_4, and rasterised this data to a spatial resolution of $50 \mathrm{~m} \times 50 \mathrm{~m}$. The TIN only covers those areas included in the WAQUA model. For areas outside the WAQUA configuration we used the AHN5 (Actueel Hoogtebestand Nederland) DEM, which covers the Netherlands at a resolution of $5 \mathrm{~m} \times 5 \mathrm{~m}$. Again, this DEM was resampled to a resolution of $50 \mathrm{~m} \times 50 \mathrm{~m}$ in ArcGIS.

\subsection{Develop stage-discharge relationships}

Stage-discharge $(Q-h)$ relationships show the relationship between discharge $(Q)$ at a given point and the river stage $(h)$ at that or another point; they can either be observed or derived from models. For a review on the use of $Q-h$ relationships, the reader is referred to Braca (2008). For the Dutch Meuse, RWS Limburg annually updates stagedischarge data. In this study, we used stage-discharge data from the Meuse WAQUA schematisation J09_4, supplied by RWS Limburg. These data show the discharge at Borgharen and St. Pieter, and the corresponding water level at each river kilometre for several return periods up to $1250 \mathrm{yr}$. Floodscanner first assigns these values to the correct river kilometre in the river network raster, and then estimates values for each intervening river cell through linear interpolation. For each river cell, a $Q-h$ relationship is then derived in the form:

$h=a Q^{b}$

where $h$ is the water level (in metres above the Dutch standard vertical datum, i.e. Normaal Amsterdams Peil (NAP)), $Q$ is the discharge at Borgharen $\left(\mathrm{m}^{3} \mathrm{~s}^{-1}\right)$, and $a$ and $b$ are coefficients empirically derived from the data described above.

\subsection{Simulate planar water-level surface}

The discharge at Borgharen (upstream) is given to the model as input. The model then estimates the corresponding water level at each river grid-cell based on the $Q-h$ relationships described above. All grid-cells in the study area are assigned to their nearest river kilometre grid-cell based on the Euclidean distance. This results in a theoretical planar water-level surface for the entire case study area.

\subsection{Estimate flood inundation depth}

To estimate inundation depths, the elevation of each grid-cell is subtracted from the planar water level surface. This, however, results in cells being inundated even when there is no 
flow connection with the river itself. Hence, we removed inundated cells not connected to the river via a flow-path with direct connectivity (in at least one of 8 directions). Furthermore, there are about 40 small dike-rings in the case-study area that provide protection against floods with return periods up to $250 \mathrm{yr}$. As the horizontal resolution of the elevation data was too coarse to provide the correct elevation of these embankments, we added a function that ensures that cells belonging to these dike-rings cannot be flooded if discharge is lower than the design discharge. The design discharge was taken from the official guidelines, i.e. $3278 \mathrm{~m}^{3} \mathrm{~s}^{-1}$ (Van de Langemheen and Berger, 2001).

\subsection{Damage modelling: Damagescanner}

We calculated the potential direct economic damage using the Damagescanner model (Aerts et al., 2008; Klijn et al., 2007). Damagescanner has been described in several studies (e.g. Aerts and Botzen, 2011; Aerts et al., 2008; Bouwer et al., 2009, 2010; De Moel et al., 2011; Te Linde et al., 2011), so we only provide a brief overview here.

Damagescanner needs two inputs: a land use map and an inundation map. The land use map (for year 2000) is derived from the Landuse scanner model (Hilferink and Rietveld, 1999) for the Rhine and Meuse basins described in detail by Te Linde et al. (2011). The map shows land use at a spatial resolution of $250 \mathrm{~m} \times 250 \mathrm{~m}$, but was resampled onto a grid with $50 \mathrm{~m} \times 50 \mathrm{~m}$ spatial resolution in order to use it in Damagescanner. The inundation maps were derived from Floodscanner, as described above. Damagescanner combines information on land use and inundation depth using stagedamage functions (SDFs), which estimate the expected damage for a given inundation depth ( $x$-axis) and a given land use (different curves) for each grid-cell; the SDFs used by Damagescanner are shown in Fig. 3. These SDFs are derived from HIS-SSM (the standard damage model used in the Netherlands) model results (Kok et al., 2005), which in turn uses damage curves that are mainly based on expert judgement, though supplemented with empirical data (see, for example, Meyer and Messner, 2005). The damage estimations of HISSSM and, thus, the Damagescanner, include about $5 \%$ indirect damages (mainly business interruption), so mainly direct damages are addressed (Wouters, 2005).

We added a function to the coupled FloodscannerDamagescanner model that prevents damage from occurring in cells that are actually contained in the channel bed. Given the resolution of the land use data $(250 \mathrm{~m} \times 250 \mathrm{~m})$, we found that some land use cells were in locations through which the river flows whilst still within its bank; clearly this situation would lead to a large overestimation of damage. Hence, we developed a mask showing the spatial extent of the river at bankfull discharge, and used this to mask the inundation map before performing the damage calculations. In order to ensure consistency with the inundation maps, the bankfull discharge mask was generated using Floodscanner, whereby the

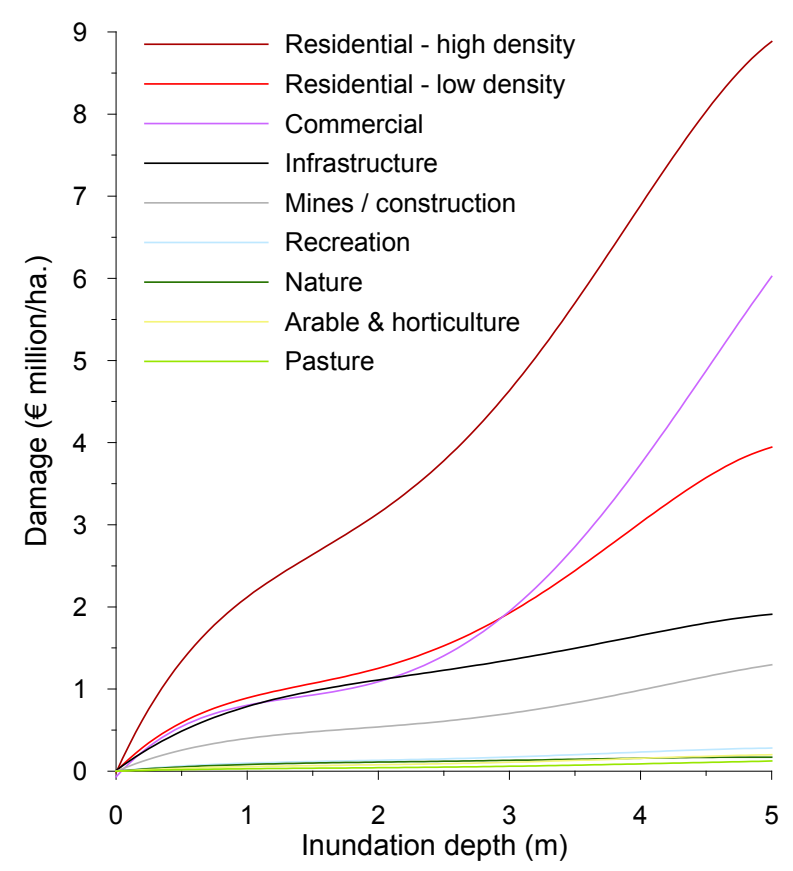

Fig. 3. Stage-damage functions used in the Damagescanner.

input discharge at Borgharen was an estimate of bankfull discharge based on the assumption that bankfull discharge is approximately equal to a flow with return period of $1.5 \mathrm{yr}$ (e.g. Dunne and Leopold, 1978; Van Looy et al., 2008). This was estimated at $1473 \mathrm{~m}^{3} \mathrm{~s}^{-1}$, based on the official HR2001 guidelines.

\subsection{Risk calculation}

Flood risk, expressed as the expected annual damage, was assessed by calculating the area under the risk curve. Hence, we required estimates of flood damage for different exceedance probabilities (return periods). Discharges at Borgharen corresponding to specified return periods ( 2 to $10000 \mathrm{yr}$ ) were calculated using the standard formulae provided in the HR2001 guidelines (Van de Langemheen and Berger, 2001):

For $2 \leq \mathrm{RP} \leq 250, \quad Q=352.9 \times \ln (\mathrm{RP})+1329.6$

For $250 \leq \mathrm{RP} \leq 10000, \quad Q=324.4 \times \ln (R P)+1486.8$

where $\mathrm{RP}$ is the return period (years) and $Q$ is the discharge at Borgharen $\left(\mathrm{m}^{3} \mathrm{~s}^{-1}\right)$.

The damage was then calculated for the different return periods, and risk curves then derived based on different combinations of exceedance probability and damage, to examine their effects on the risk estimation. Risk was calculated as the area under the risk curve approximated using the trapezoidal rule (e.g. Meyer et al., 2009). 


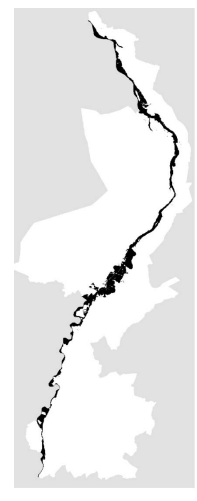

Observed - 1993
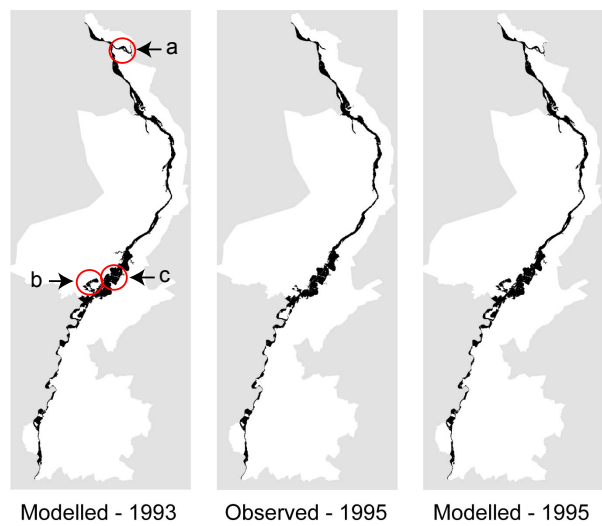

Fig. 4. Inundation extent maps based on aerial photography and satellite imagery (observed) and Floodscanner (modelled) for the floods of 1993 and 1995. The red circles show two locations at which the model did not perform well (a: confluence of the Niers and the Meuse rivers and b: the lake known as the Lange Vlieter, completed post-1995) and a location at which the model performed very well (c).

\section{Results}

The results section is split into two main parts: firstly, we discuss the validation of the coupled FloodscannerDamagescanner model results, and secondly we discuss the flood risk estimates derived from the analyses.

\subsection{Validation}

\subsubsection{Inundation estimates}

In order to verify the quality of the method in producing inundation maps usable in studies of flood damage and risk, we compare: (a) our inundation extent maps with observed inundation extents for the floods of 1993 and 1995; and (b) our inundation depth maps with those produced using WAQUA for RWS Limburg.

Maps showing the extent of the inundated area during the floods of 1993 and 1995, based on aerial photography and satellite imagery, were provided by RWS Limburg. The floods of 1993 and 1995 had discharges at Borgharen of $3120 \mathrm{~m}^{3} \mathrm{~s}^{-1}$ and $2861 \mathrm{~m}^{3} \mathrm{~s}^{-1}$ (Wind et al., 1999), corresponding to return periods of ca. 160 and $77 \mathrm{yr}$, respectively, using the formulae in the HR2001 guidelines. Hence, we used these discharge values to run Floodscanner and derive modelled inundation maps. The observed and modelled flood events were then compared; the results are shown for the entire case-study river section in Fig. 4, and in detail for three locations in Fig. 5. Note that since Floodscanner assumes that all dike-ring areas are fully protected against floods with return periods up to $250 \mathrm{yr}$, we also removed any inundated cells in the observed dataset within the dike-ring areas. This is because some areas within the dike rings did, in fact, flood

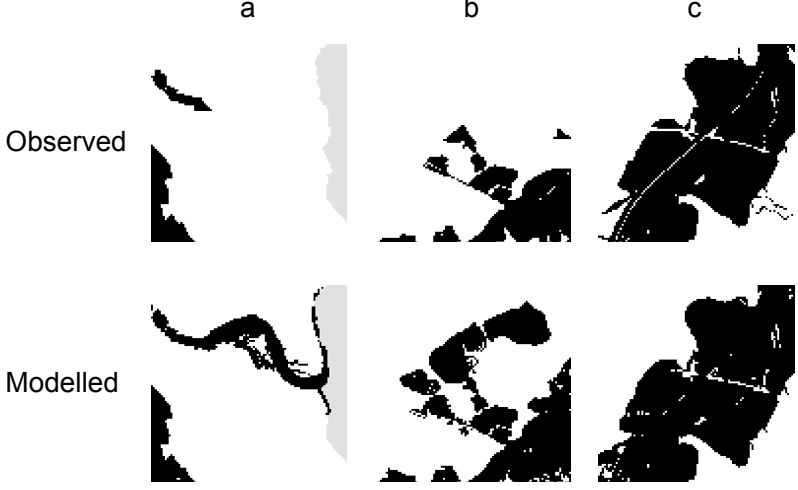

Fig. 5. Detailed view of the inundation extent maps for 1993 (observed and modelled) for the three locations shown in Fig. 4. The model did not perform well at locations a (confluence of the Niers and the Meuse rivers) and $b$ (the lake known as the Lange Vlieter, completed post-1995). Location c shows an example of a river stretch where the model performed well.

during the 1993 and 1995 floods, but since then extensive works have been carried out to ensure that the safety standards are met.

In Table 1, we show the number of cells inundated in the observed datasets only, the modelled datasets only, and the number of cells inundated in both datasets. The agreement between the datasets is strong. Reference to the maps (Fig. 4) shows only a few locations with large differences. For example, the modelled maps show an inundation area at the confluence of the Niers tributary and the Meuse (shown by circle a in Fig. 4, and in Fig. 5). Clearly, the simplified inundation model developed for this study has difficulty in dealing with hydraulically complicated backwater effects. A second source of anomalies is around several of the new "Maasplassen"; these lakes have been created by sand and gravel mining, and some were not completed until after 1995 (e.g. the Lange Vlieter, shown by circle b in Fig. 4, and in Fig. 5). Hence, these lakes are "inundated" in the model, but were not inundated in 1993 and 1995 because at that time the gravel and sands had not been extracted. Figure $5 \mathrm{c}$ shows a closeup of an example location where the model performs well. Of the cells that were inundated in the modelled dataset only (Table 1), approximately 1850 cells are located in locations $\mathrm{a}$ and $\mathrm{b}$ of Figs. 4 and 5.

Next, we compared the simulated inundation depths with those simulated using WAQUA for RWS Limburg. The WAQUA results were provided by RWS Limburg for the following return periods: $2,5,20,75,250$ and $1250 \mathrm{yr}$; they are derived from WAQUA version 2005-02, model schematisation J09_4. The depth anomalies per grid-cell (Floodscanner minus WAQUA) are shown in Fig. 6. As the return period increases, so too does the spread between the two datasets, as would be expected. The figures show that Floodscanner overestimates inundation depths at very low return periods 
Table 1. Number of inundated cells in the observed dataset, the modelled dataset, and number of cells that are inundated in both datasets. Of the cells that were inundated in the modelled dataset only, approximately 1850 cells are located in locations a and b of Figs. 4 and 5.

\begin{tabular}{cccc}
\hline & \multicolumn{3}{c}{ Number of inundated cells } \\
\cline { 2 - 4 } Year & Observed dataset only & Modelled dataset only & Both datasets \\
\hline 1993 & 48867 & 53291 & 47497 \\
1995 & 47639 & 51982 & 46511 \\
\hline
\end{tabular}

( $2 \mathrm{yr}$ ), has little bias at medium return periods (up to $20 \mathrm{yr}$ ) and slightly underestimates inundation depths at high return periods (from $75 \mathrm{yr}$ upwards) with respect to the WAQUA estimates. Overall, for the return periods shown, the anomaly is $\leq 0.5 \mathrm{~m}$ for $71 \%(\mathrm{RP}=1250 \mathrm{yr})$ to $93 \%(\mathrm{RP}=75 \mathrm{yr})$ of the cells; and the anomaly is $\leq 1 \mathrm{~m}$ for $91 \%(\mathrm{RP}=1250 \mathrm{yr})$ to $97 \%(\mathrm{RP}=20 \mathrm{yr})$ of the cells. This is encouraging, since research carried out by De Moel and Aerts (2011) in the Netherlands shows that an overall change in the inundation level by $0.5 \mathrm{~m}$ may lead to a change in damage by a factor of 1.35-1.44, whilst an overall change in the inundation level by $1 \mathrm{~m}$ may lead to a change in damage by a factor of ca. 2 .

\subsubsection{Damage estimates}

We validated the results of the coupled FloodscannerDamagescanner system by using the Damagescanner model to calculate damage for several return periods based on inundation maps from both: (a) Floodscanner; and (b) the official flood inundation maps ("Risicokaart") for the Meuse. The latter are used for communicating risk to the general public, and were provided by RWS Limburg for several return periods. We used the return periods 100, 945 and $1250 \mathrm{yr}$ for validation. Several other maps are available for lower return periods ( 50 and $250 \mathrm{yr}$ ); however, the maps provided for those return periods allowed flooding in the dike-ring areas despite probabilities below the safety levels, so they are not comparable to the Floodscanner maps. The results of this analysis are shown in Table 2. The relative difference between Floodscanner and Risicokaart is small for the higher return periods ( 945 and $1250 \mathrm{yr}$ ), yet larger for the simulation with a return period of $100 \mathrm{yr}$ (Risicokaart is $45 \%$ higher than Floodscanner). This is consistent with the results of the inundation model validation discussed in Sect. 4.1.1.

We also compared the results of the coupled FloodscannerDamagescanner model with results from several other sources. Wind et al. (1999) report on observed damages in Dutch Limburg following the flood events of 1993 and 1995, based on damage assessments commissioned by the Dutch government. They report direct economic damages in the 1993 and 1995 floods as $€ 149$ million and $€ 91$ million, respectively, compared to $€ 283$ and $€ 238$ for our model. The
Table 2. Total damage simulated using Damagescanner with inundation maps of Floodscanner and Risicokaart: for both sets of inundation maps the results are shown for three return periods (RP) (100, 945 and 1250).

\begin{tabular}{lccc}
\hline & \multicolumn{3}{c}{ Total damage (€ million) } \\
\hline & RP 100 & RP 945 & RP 1250 \\
\cline { 2 - 4 } Risicokaart & 408 & 2167 & 2505 \\
Floodscanner & 279 & 2144 & 2281 \\
\hline
\end{tabular}

estimates of Wind et al. (1999) are based on reported damages. Our simulations are substantially larger than this estimate (though note that Damagescanner inherently includes about $5 \%$ indirect damages). In Table 3, we show the damage per land use category for the floods of 1993 and 1995 as reported by Wind et al. (1999), and as estimated using our model. Note that the damage categories have been reclassed to those reported in Wind et al. (1999) as described in the caption of Table 3. In 1993, the agreement between all categories is reasonable, except for the class "Agriculture and horticulture". To some extent, we would expect the modelled damage in the agricultural classes to be higher than the reported values, since Damagescanner also accounts for damage to buildings (e.g. residential houses) located on cells designated as agriculture on the land use map. This could also account for part of the difference between the values for damage category "Private". However, the discrepancy for the damage category "Agriculture and horticulture" is very large. In terms of damage to crops, the SDFs used in Damagescanner assume that the harvest is lost at maximum damage. However, this would only be the case if a flood occurred during the growing season, which was not the case in 1993 or 1995 (winter floods). The results in Table 3 also show that the discrepancy between the reported and modelled damage in 1995 for damage property "Private" (which corresponds to residential in Damagescanner) is greater than in 1993. Wind et al. (1999) note that approximately $50 \%$ of the reduction in total damage between 1993 and 1995 can be attributed to a reduction in damages to households as a result of a marginal increase in flood warning time and the experiences gained by the public following the 1993 floods (e.g. Botzen et al., 2009a, b). These factors are not included in Damagescanner, which assumes constant susceptibility of populations to flooding over time. The implications of these findings are discussed in Sect. 5.1.

\subsection{Flood risk assessment results}

To estimate flood risk, we calculated damages associated with certain return periods and then calculated the area under the risk curve that was constructed using these data points. To get the most detailed result of the integrations, we first 

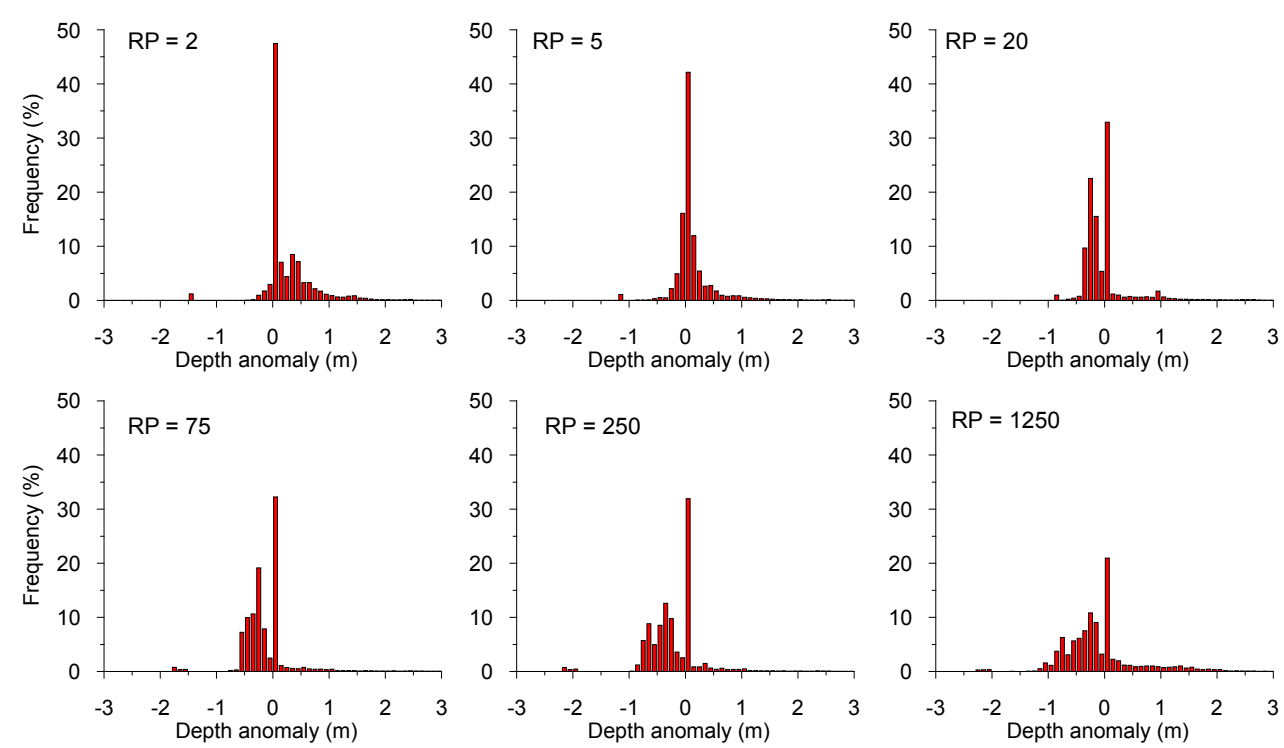

Fig. 6. Frequency distributions (\%) of the differences between the inundation depths (in metres) per grid-cell from the inundation maps produced using Floodscanner minus the WAQUA inundation maps for different return periods (RP).

Table 3. Estimated damage per land use category for the floods of 1993 and 1995 according to Wind et al. (1999) (updated to year 2000 Euros) and the results of the coupled Floodscanner-Damagescanner model (modelled). Note that the damage categories of the Damagescanner have been reclassed to those reported by Wind et al. (1999) in order to allow comparison. The reclass was carried out as follow (Private $=$ Residential (high and low density); Agriculture and horticulture $=$ Arable and horticulture, Pasture; Trade and industry $=$ Commercial, Mines/Construction; Institutions and government = Infrastructure, Recreation, Nature).

\begin{tabular}{lcccc}
\hline & \multicolumn{4}{c}{ Damage ( $€$ million) } \\
\cline { 2 - 5 } Damage category & Wind et al. (1993) & Modelled (1993) & Wind et al. (1995) & Modelled (1995) \\
\hline Private & 57 & 87 & 23 & 73 \\
Agriculture and horticulture & 11 & 141 & 12 & 119 \\
Trade and industry & 43 & 34 & 34 & 28 \\
Institutions and government & 38 & 22 & 23 & 18 \\
Total & 149 & 283 & 91 & 238 \\
\hline
\end{tabular}

calculated flood risk based on damage estimates for return periods of 2 to $10000 \mathrm{yr}$, with intervals of $1 \mathrm{yr}$. We also assumed damage at bankfull discharge $(\mathrm{RP}=1.5 \mathrm{yr})$ to be zero and included this in the risk curve. This resulted in the flood risk curve shown in Fig. 7; the associated flood risk is ca. $€ 34$ million p.a. (Note that the figures on the left and right show the same information, but the $\mathrm{x}$-axis on the right has been plotted on a logarithmic scale). The curves are based on 10000 flood inundation and damage simulations carried out with the coupled Floodscanner-Damagescanner model. Note the step-change in damage at a return-period of $250 \mathrm{yr}$ (exceedance probability $=0.004$ ); this is due to the fact that the dike-ring areas are nominally protected up to this return-period and, therefore, we have assumed no inundation in those areas for discharges with a lower return-period.

\subsubsection{Effect of selection of three return periods on annual risk}

We then tested how the above risk estimate compares to an estimate based on three flood hazard maps (low, medium and high probability), i.e. as required by the European Flood Directive (2007/60/EC). For high probability, we used a return period of $10 \mathrm{yr}$, for medium probability we used $250 \mathrm{yr}$ (assuming the small dike rings would not flood), due to its relevance as the design discharge for dike-ring areas in Dutch Limburg; and for low probability we used $1250 \mathrm{yr}$. We used $1250 \mathrm{yr}$ since it is also an important return period in Dutch water management, being the design standard for river flood protection downstream from Dutch Limburg. Again, we assumed zero damage at bankfull discharge, enabling us to 

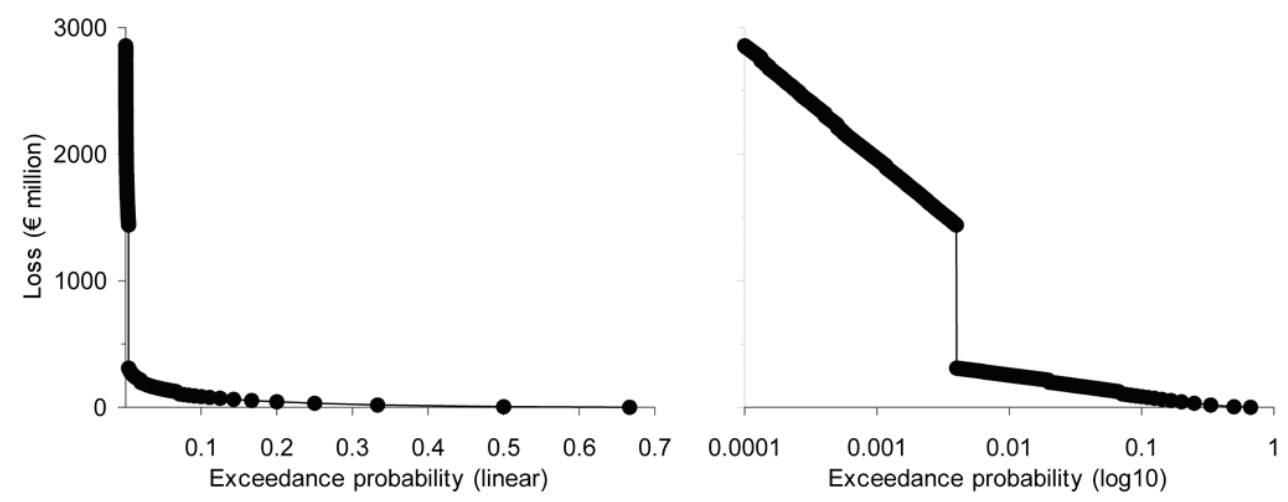

Fig. 7. Risk curve for flood losses with return-periods from 2 to $10000 \mathrm{yr}$ (in steps of 1), based on the official guideline HR2001. The curve is shown with exceedance probability on a linear scale (left) and logarithmic scale (right). The area under the curves is the expected annual damage, or risk; in this case ca. $€ 34$ million p.a.

make the risk calculation upwards from zero damage. This resulted in an estimate of risk of ca. $€ 47$ million p.a., i.e. $38 \%$ higher than that based on the damage estimate for 10000 return periods.

We then carried out sensitivity analyses to examine the effects of using different return periods for the low and high probability events, but still using three return periods to estimate risk. We varied the return-period of the high probability flood between 2 and $25 \mathrm{yr}$, and the low probability flood between 500 and $10000 \mathrm{yr}$ (both with intervals of one year). The minimum risk estimate based on all combinations of these values is $€ 44$ million p.a., whilst the maximum is $€ 67$ million p.a. Hence, the selection of these three data points always led to a higher estimation of risk compared to the estimate made with all return periods from 2 to $10000 \mathrm{yr}$. This is mainly caused by the fact that the risk curve between return periods of 2 to $250 \mathrm{yr}$ is highly concave and, therefore, a linear interpolation between these points (as in the former example) results in an overestimation of risk.

\subsubsection{Effect of safety protection on risk}

Also, we realise that the selection of the medium probability flood as that with return-period of $250 \mathrm{yr}$ may influence the results, since at this discharge, we assume that no flooding occurs within the small dike-ring areas of the Meuse valley, whilst it is allowed to occur at a return period of $251 \mathrm{yr}$. Hence, we also calculated risk based on damage estimates for the following return periods: 10, 250, 251 and $1250 \mathrm{yr}$. This resulted in a risk estimate of ca. $€ 48$ million p.a., i.e. only marginally more than the estimate not including the return-period of $251 \mathrm{yr}$. However, if we carry out the risk calculation based on the damage estimates for only 10, 251 and $1250 \mathrm{yr}$ (i.e. excluding 250), the risk is $€ 103$ million p.a. This large difference in calculated risk (just over a factor 2 difference) demonstrates that the assumption of binary flooding (flood/no-flood) up to a design level has a critical affect on the calculated risk. It is, therefore, crucial to have a grasp on failure probabilities of embankments in order to reduce the uncertainty in the flood risk calculation introduced by such binary assumptions.

\subsubsection{Effect of choice of lowest return period on risk}

Often, in flood risk analysis, the flood risk curve does not start at a discharge corresponding to zero damage, as we did here, but at some arbitrary point along the theoretical risk curve. To test the effect of such an approach, we also calculated the annual risk based on damage estimates for returnperiods 10,250 and $1250 \mathrm{yr}$, but taking the return period of $10 \mathrm{yr}$ as the lowest data point on the curve (i.e. not the value of zero damage at bankfull discharge). This resulted in an annual risk of ca. $€ 23$ million p.a., i.e. $33 \%$ less than the estimate made for the entire curve (2-10000 yr).

\subsubsection{Effect of choice of highest return-period on risk}

To assess the effect of the choice of the maximum return period used to calculate annual risk, we calculated risk using different maximum return periods. Starting with a maximum return period of $2 \mathrm{yr}$, risk was calculated using risk curves with successive maximum return periods increasing with $1 \mathrm{yr}$ intervals. All data points corresponding to return periods lower than the maximum return period were taken into consideration to estimate the annual risk (Fig. 8). For example, for the point on the graph in Fig. 8 at which maximum return period is equal to $2000 \mathrm{yr}$, we calculated the risk using estimates of damage for all discharges with return periods from 2 to $2000 \mathrm{yr}$ inclusive (with a step of one year). This same procedure was carried out up to a maximum return period of 10000 yr. In Fig. 8, we show how the annual flood risk estimate increases as the maximum return period used to estimate that risk increases. It is interesting to see that the curve flattens off rather abruptly at return periods between 1000 and $2000 \mathrm{yr}$. In fact, when a maximum value 


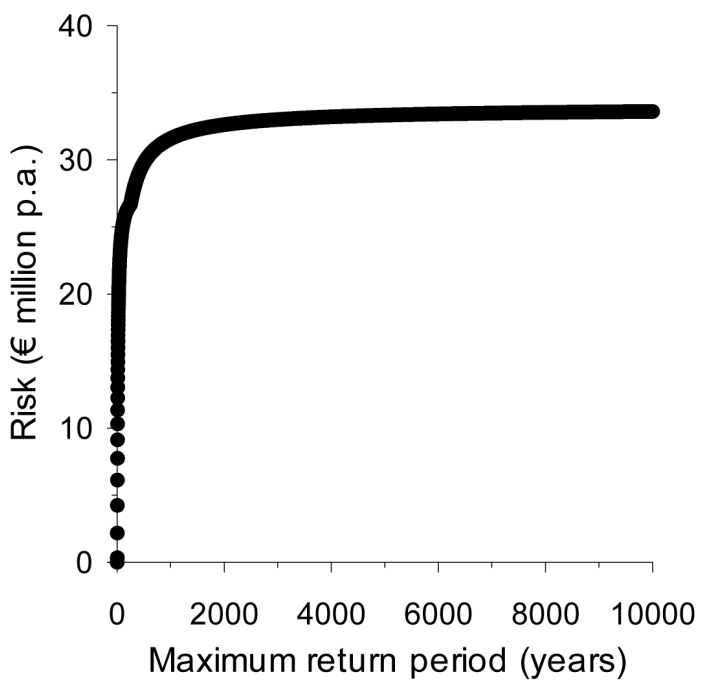

Fig. 8. Figure showing risk when calculated using different maximum return periods. For example, for the point on the graph at which maximum return period is equal to 2000 , we calculated the risk using estimates of damage for all discharges with return periods from 2 to $2000 \mathrm{yr}$ inclusive (with steps of one year).

of $1250 \mathrm{yr}$ is used (the value usually used for low probability floods in the Netherlands), the risk is ca. $€ 32$ million p.a., which is just $5 \%$ lower than that using all return periods up to $10000 \mathrm{yr}$ ( $€ 34$ million p.a.).

Figure 8 also shows that the influence of floods with relatively low return periods on the risk is relatively high as risk shows a steep increase for low values of maximum return period used. In other words, low return period floods are responsible for a relatively large part of the total expected annual damage.

\subsubsection{Estimating risk based on six return periods}

Messner et al. (2007) state that preferably six flood return periods should be used for estimating flood risk. We, therefore, tested whether the use of six periods did indeed provide a good estimate of risk, compared to the estimate based on the entire risk curve for all return periods from $\mathrm{RP}=1.5$ to $10000 \mathrm{yr}$. To carry out this assessment, we fixed four of the return periods used, namely: (a) $\mathrm{RP}=1.5 \mathrm{yr}$, since we have shown that it is of great importance to extrapolate the curve back to the return period at which zero damage occurs; (b) $\mathrm{RP}=250 \mathrm{yr}$ and $\mathrm{RP}=251 \mathrm{yr}$, since we have also shown the importance of including damage estimates for return periods just above and below the period for which flood defences are designed; and (c) $\mathrm{RP}=10,000 \mathrm{yr}$, since this is the highest return period for which we have estimated the damage. We then allowed the other two return periods to vary and estimated risk for each each possible combination (100 million combinations). This resulted in estimates of flood risk ranging from $€ 41$ million p.a. to $€ 111$ million p.a. (compared to $€ 34$ million p.a. for the estimate based on all return periods). The risk estimate with six return periods that is closest to the estimate using the full curve was based on the following return periods: $1.5,4,14,250,251$ and $10000 \mathrm{yr}$. This shows that even if we use the optimal combination of six return periods, the risk estimate is still ca. $21 \%$ higher than that based on the full risk curve from $\mathrm{RP}=1.5$ to $10000 \mathrm{yr}$. Moreover, it also shows that the most accurate estimates are achieved when the number of return periods used is increased in the lower tail of the risk curve (i.e., the high-occurrence, low consequence events). Adding an extra return period in the upper tail (e.g. at $\mathrm{RP}=1000 \mathrm{yr}$ ) has very little influence on the final risk estimate.

\section{Discussion}

\subsection{Comparison to past inundation and damage studies in Dutch Limburg}

Bates and De Roo (2000) developed a physically-based flood inundation model (LISFLOOD-FP) and used this to simulate flood extents of the 1995 floods over a $35 \mathrm{~km}$ section of the Meuse in Dutch Limburg. The model is an extension of the LISFLOOD catchment model designed for channel and floodplain hydraulic routing. It consists of 1-D kinematic wave approximation for channel flow solved using an explicit finite difference scheme and a 2-D diffusion wave representation of floodplain flow. The model results were compared with those of several different methods; the flood extents simulated by all models were checked against air photo and Synthetic Aperture Radar (SAR) data of the flood inundation extent. The model performed well, correctly predicting $81.9 \%$ of inundated and non-inundated cells; this is of a similar order as our rapid inundation modelling approach. However, it should be noted that our simple approach is not capable of correctly simulating hydrodynamic processes either inside or outside the river channel and, therefore, larger differences would be expected on more hydrologically complicated river stretches. For example, we see that Floodscanner may overestimate inundation extent (and depth) in river confluences, since it is not capable of simulating backwater effects.

Whilst our simulated damages for the flood events of 1993 and 1995 ( $€ 283$ million and $€ 238$ million, respectively) are greater than the estimates of Wind et al. (1999) ( $€ 149$ million and $€ 91$ million, respectively), they are of the same order of magnitude. Part of the difference may be explained by the fact that the estimates of Wind et al. (1999) are based on reported damages, whilst in reality some actual damages incurred may not have been reported. We have identified two other main factors that could account for the discrepancy. Firstly, the modelled damage in agricultural areas is much larger than the damage reported by Wind et al. (1999). This is partly due to the fact that damage to residential buildings in 
grid-cells with an agricultural land use is also accounted for in the SDFs of agricultural land use types in Damagescanner. However, the discrepancy seems too large to be accounted for by this factor alone. The SDFs of the agricultural land use classes in Damagescanner assume a constant economic value of the productive component (i.e. crops, livestock, etc.) throughout the year. In reality, the damage that would actually occur is highly dependent on the season in which a flood occurs (e.g. Förster et al., 2008). Since most floods of the Meuse River occur during the winter season, this means that the standard SDFs will overestimate damage to agriculture. Damagescanner could be improved by integrating information on the seasonal distribution of agricultural losses; examples of studies that use a seasonal approach can be found in Förster et al. (2008). The second major cause of discrepancy between the modelled damages and those reported by Wind et al. (1999) is caused by damage from the category "Private" in 1995 (the majority of which is damage to residential properties). The difference between the modelled and reported values is much greater in 1995 than in 1993, since actual damage to households was reduced in the former due to a marginal increase in flood warning time and the experiences gained by the public following the 1993 floods (Wind et al., 1999). The SDFs used in Damagescanner have no memory for past events, i.e. they remain constant through time whether an area has previously been flooded or not. A recent study of Elmer et al. (2010) attempted to integrate information on flood frequency into SDFs for Germany, since they also found an overestimation of flood damage in damage models for floods with low to medium return periods as a result of private adaptation based on past experience. Further research into the incorporation of these two aspects (seasonal SDFs for agricultural land uses and SDFs incorporating information on flood frequency) could benefit flood risk estimates in damage models more broadly.

Even in this region, which has a relative abundance of data on hydrological issues, the poor availability of highresolution observed damage data makes verification extremely difficult. This is a recurring theme in flood damage modelling (e.g. Merz et al., 2010b). However, remembering that a main aim at hand is to assess how flood risk estimates are affected by the return-periods used to develop flood risk curves, our estimates appear accurate enough to give meaningful results. Naturally, as with all flood damage models, the absolute results should be treated with caution.

\subsection{Effect of return-periods used to assess flood risk}

Our findings illustrate that the choice of the return-periods used to construct the exceedance probability-loss curve (or risk curve) can have a large influence on the estimate of risk. This has potentially large implications, since most risk estimates tend to be made based on damage estimates made for a very limited number of return periods. For example, in the EFD, member states are currently only obliged to create flood hazard maps for three classes of floods (De Moel et al., 2009), on which risk management plans should be based (2007/60/EC). Moreover, we have shown that even if we use a risk curve based on damage estimates for six return periods, the risk is overestimated by between $21 \%$ (for the optimal choice of the six return periods) and $226 \%$ (for the least optimal choice of the six return periods).

Our research also shows, similar to that of Merz et al. (2009), that floods with a relatively high probability (thus, low return period) have a large influence on the annual risk. Whilst these floods may cause relatively low economic damage per event, their relatively frequent occurrence means that they should be fully considered in flood risk assessments. This is an important point to be addressed, since many major flood risk studies tend to focus on the effects of extreme events. On the other hand, whilst the most extreme flood events may have a relatively small effect on overall direct economic risk in this study area, the potential impacts should they occur extend far greater than simply direct economic damage. Events with very low probabilities may cause more social disruption, casualties and indirect damages. In general, an annual risk corresponding to a very rare event is socially less desirable than a more common event with the same annual risk (see, for example, Merz et al., 2010a).

The results also show that large differences in risk estimates can be derived when risk curves commence and/or end at some arbitrary position on the flood risk curve. It is, therefore, of utmost importance to estimate the flood return-period at which damage commences in order to develop the curve back to this point. Effort should also be expanded on estimating the return-period above which there is little affect on annual risk, so that a judgment can be made on the maximum return-period required to develop a reasonable estimate of annual risk. Based on the results of our study, we can also state that in areas that are heavily protected by flood defences, events with return periods just below and just above, the design level should be used to account for the jump in the risk curve.

\subsection{Limitations and applications}

In this paper, we have developed a simple inundation model and coupled it to a flood damage model. The simplifications also dictate the application of the method. The Floodscanner method is certainly not intended to replace the need for hydraulic modelling with more complex models. We emphasize that this approach is neither suitable for localised flood risk assessments (e.g. street to city scale), nor for presenting flood risk at the grid-cell level. Flood damage estimates at such fine resolutions need to employ more state-of-the-art methods that have been clearly designed for those applications (e.g. Ernst et al., 2010).

Rather, the approach is intended to be complementary to such methods for use in reach-to-basin scale studies in which large numbers of inundation maps are required. For example, 
where accurate basin-wide flood risk estimates are required, it may be useful to first employ a method such as Floodscanner to identify the (number of) data points that are needed on the risk curve to estimate risk, since it can provide an indication of the risk curve's sensitivity to the return-periods used. Once these have been established, it may still be preferential to employ a more complex process-based model to simulate inundation for a selected number of return-periods.

In addition, the coupled methodology is useful for Monte Carlo based uncertainty analyses (e.g. Apel et al., 2008), probabilistic impact assessments (e.g. New et al., 2007), and the evaluation of combinations of many different future projections. In the latter case, Floodscanner can be used to derive change factors for the many different future projections, which can then be applied to detailed baseline estimates of risk under current conditions using damage estimates based on the most state-of-the-art process models. As illustrated, there are many cases where large numbers of model evaluations are useful. This shows that more attention is needed on the development of relatively simple inundation models. The method developed and applied here is capable of this, but refinements could be added to include the most important physical processes in a simple manner.

Finally, since the main aim of this study is to assess the influence on risk of the return-periods used to estimate that risk, we do not examine other sources of uncertainty in this paper. At each stage of the modelling process, large uncertainties can be introduced, and a full flood risk assessment should attempt to assess their influence on the final risk estimates. In this paper, we show the sizeable uncertainty that can be added to those estimates through an arbitrary selection of return periods and binary assumptions on defence failure for the derivation of risk. Future applications of the model should attempt to estimate the uncertainty associated with the different parts of the model chain and input data (e.g. De Moel and Aerts, 2011).

\section{Conclusions}

The main aim of this paper was to examine how flood risk estimates are affected by the selection of return-periods used to estimate the risk. In order to do this, we developed a coupled inundation-damage model designed to rapidly estimate the economic damage associated with floods of thousands of return-periods. The damage model component, Damagescanner, is an existing model, but we dynamically coupled this to a new inundation model: Floodscanner. Floodscanner performed reasonably well compared to historical floods of 1993 and 1995, as well as compared to results from a processbased 2-D hydrodynamic model (WAQUA). However, 2-D hydrodynamic models will always be better suited for local scale flood risk analysis and Floodscanner does not aim to replace these more detailed process-based models. Rather, it intends to supplement these existing numerical models for experiments in which a large number of model evaluations are necessary, like the research presented in this paper. In addition, the Floodscanner can be useful to perform uncertainty and sensitivity analyses, probabilistic impact assessments, and for the evaluation of many different combinations of future scenarios.

This methodology was subsequently used to investigate how flood risk calculations from risk curves are affected by the amount and choice of return periods used to develop the curve. Firstly, we estimated the risk based on a risk curve for all return periods from 2 to $10000 \mathrm{yr}$, with a step of one year (i.e. $€ 34$ million p.a.). Compared to this estimate, we found that when using three return periods to develop the risk curve (low, medium and high probability, whereby medium probability is $\mathrm{RP}=250 \mathrm{yr}$ ), risk estimates were overestimated by between $33 \%$ and $100 \%$. We also found that using six return periods to estimate flood risk led to an overestimation of risk, even if those six return periods were chosen optimally. The overall risk is greatly affected by the number of data points used to construct the part of the curve for high probability floods, even though much research tends to focus on extreme events with very low probability. Moreover, the lowest return period point used in the risk curve also influences the risk estimate considerably. For example, excluding a zero damage data point and taking $10 \mathrm{yr}$ as the lowest return period resulted in an underestimation of about $33 \%$ compared to the risk estimate derived from the entire curve. The influence of different maximum return periods used to construct the risk curve is very high up to return periods of between 1000 to $2000 \mathrm{yr}$, but levels off rapidly at higher return periods. Besides the number of points, binary assumptions on the failure of flood defences also greatly influence the risk estimate, by about a factor of two.

The results suggest that more research is needed to develop relatively simple inundation models that can be used to produce large numbers of inundation maps, complementary to the more complex 2-D-3-D hydrodynamic models. It also suggests that research into flood risk could benefit from paying more attention to the damage caused by relatively high probability floods (as long as they cause damage), since these have a large influence on the risk as derived from a risk curve. The research also highlights two problems in the use of stationary SDFs for estimating flood damage, namely: (a) using annual SDFs for agricultural land uses led to over-estimations of observed floods that occurred outside the growing season; and (b) the SDFs do not incorporate information on flood frequency, meaning that they do not account for the fact that people regularly exposed to flooding may take individual adaptive measures that reduce the damage in the event of future floods. Flood risk research in the Netherlands (and elsewhere) could benefit from incorporating these aspects in their standard flood risk assessment methods. 
Acknowledgements. This research was carried out in the framework of the Dutch knowledge programmes Knowledge for Climate (HSGR06 and Theme 1) and Climate changes Spatial Planning (A20 and IC3) (www.klimaatonderzoeknederland.nl). We thank two anonymous reviewers for their useful comments; Siebolt Folkertsma and Willinda Rhebergen (RWS Limburg) and the Province of Limburg for providing datasets; and Hermjan Barneveld and Jan Huizinga (HKV) for discussions on the methods used.

Edited by: T. Glade

Reviewed by: two anonymous referees

\section{References}

Aerts, J. C. J. H. and Botzen, W. J. W.: Climate change impacts on pricing long-term flood insurance: A comprehensive study for the Netherlands, Global Environ. Change, 21, 1045-1060, doi:10.1016/j.gloenvcha.2011.04.005, 2011.

Aerts, J. C. J. H., Renssen, H., Ward, P. J., De Moel, H., Odada, E., Bouwer, L. M., and Goosse, H.: Sensitivity of global river discharges under Holocene and future climate conditions, Geophys. Res. Lett., 33, L19401, doi:10.1029/2006GL027493, 2006.

Aerts, J. C. J. H., Sprong, T., and Bannink, B. A.: Aandacht voor Veligheid. Report number 009/2008. Leven met Water, Klimaar voor Ruimte, DG Water, Amsterdam, 2008.

Apel, H., Merz, B., and Thieken, A. H.: Quantification of uncertainties in flood risk assessments, International Journal of River Basin Management, 6, 149-162, 2008.

Ashagrie, A. G., de Laat, P. J., de Wit, M. J., Tu, M., and Uhlenbrook, S.: Detecting the influence of land use changes on discharges and floods in the Meuse River Basin - the predictive power of a ninety-year rainfall-runoff relation?, Hydrol. Earth Syst. Sci., 10, 691-701, doi:10.5194/hess-10-691-2006, 2006.

Bates, P. D. and De Roo, A. P. J.: A simple raster-based model for inundation simulation, J. Hydrol., 236, 54-77, 2000.

Booij, M. J.: Impact of climate change on river flooding assessed with different spatial model resolutions, J. Hydrol., 303, 176198, doi:10.1016/j.jhydrol.2004.07.013, 2005.

Botzen, W. J., Aerts, J. C. J. H., and Van de Bergh, J.: Willingness of Homeowners to Mitigate Climate Risk through Insurance, Ecol. Econ., 68, 2265-2277, 2009a.

Botzen, W. J., Aerts, J. C. J. H., and Van de Bergh, J.: Factors Shaping Individual Perceptions of Climate Change Flood Risk, Water Resour. Res., 45, W10440, doi:10.1029/2009WR007743, 2009b.

Bouwer, L. M., Bubeck, P., Wagtendonk, A. J., and Aerts, J. C. J. H.: Inundation scenarios for flood damage evaluation in polder areas, Nat. Hazards Earth Syst. Sci., 9, 1995-2007, doi:10.5194/nhess-9-1995-2009, 2009.

Bouwer, L. M., Bubeck, P., and Aerts, J. C. J. H.: Changes in future flood risk due to climate and development in a Dutch polder area, Global Environ. Chang., 20, 463-471, doi:10.1016/j.gloenvcha.2010.04.002, 2010.

Braca, G.: Stage-discharge relationships in ocean channels: practices and problems. FORALPS Technical Report 11. Università degli Studi di Trento, Dipartimento di Ingegneria Civile e Ambientale, Trento, 2008.

Bultot, F., Coppens, A., Dupriez, G. L., Gellens, D., and Meulenberghs, F.: Repercussions of a $\mathrm{CO}_{2}$ doubling on the water cycle and on the water balance - A case study for Belgium, J. Hydrol., 99, 319-347, 1988.

Bultot, F., Dupriez, G. L., and Gellens, G.: Simulation of land use changes and impacts on the water balance - case study for Belgium, J. Hydrol., 114, 327-348, 1990.

De Moel, H. and Aerts, J. C. J. H.: Effect of uncertainty in land use, damage models and inundation depth on flood damage estimates, Nat. Hazards, 58, 407-425, doi:10.1007/s11069-0109675-6, 2011.

de Moel, H., van Alphen, J., and Aerts, J. C. J. H.: Flood maps in Europe - methods, availability and use, Nat. Hazards Earth Syst. Sci., 9, 289-301, doi:10.5194/nhess-9-289-2009, 2009.

De Moel, H., Aerts, J. C. J. H., and Koomen, E.: Development of flood exposure in the Netherlands during the 20th and 21st century, Global Environ. Chang., 21, 620-627, doi:10.1016/j.gloenvcha.2010.12.005, 2011.

De Wit, M., Warmerdam, P., Torfs, P., Uijlenhout, R., Roulin, E., Cheymol, A., Van Deursen, W., Van Walsum, P., Ververs, M., Kwadijk, J., and Buiteveld, H.: Effect of climate change on the hydrology of the river Meuse. Dutch National Research Programme on Global Air Pollution and Climate Change. Report number 410.200.090, RIVM, Bilthoven, 2001.

De Wit, M. J. M., Peeters, H., Gastaud, P. H., Dewil, P., Maeghe, K., and Baumgart, J.: Floods in the Meuse basin: Event descriptions and an international view on ongoing measure, International Journal of River Basin Management, 5, 279-292, 2007.

Dunne, T. and Leopold, L. B.: Water in Environmental Planning, W. H. Freeman and Company, New York, 1978.

Elmer, F., Thieken, A. H., Pech, I., and Kreibich, H.: Influence of flood frequency on residential building losses, Nat. Hazards Earth Syst. Sci., 10, 2145-2159, doi:10.5194/nhess-10-21452010, 2010.

Ernst, J., Dewals, B., Detrembleur, S., Archambeau, P., Erpicum, S., and Pirotton, M.: Micro-scale flood risk analysis base don detailed 2-D hydraulic modelling and high resolution geographic data, Nat. Hazards, 55, 181-209, doi:10.1007/s11069-010-9520y, 2010.

Fenicia, F., Savenije, H. H. G., and Avdeeva, Y.: Anomaly in the rainfall-runoff behaviour of the Meuse catchment. Climate, land-use, or land-use management?, Hydrol. Earth Syst. Sci., 13, 1727-1737, doi:10.5194/hess-13-1727-2009, 2009.

Few, R.: Flooding, vulnerability and coping strategies: local responses to a global threat, Progress in Development Studies, 3, 43-58, 2003.

Förster, S., Kuhlmann, B., Lindenschmidt, K.-E., and Bronstert, A.: Assessing flood risk for a rural detention area, Nat. Hazards Earth Syst. Sci., 8, 311-322, doi:10.5194/nhess-8-311-2008, 2008.

Gellens, D.: Impact of a CO2-induced climatic change on river flow variability in three rivers in Belgium, Earth Surf. Proc. Land., 16, 619-625, doi:10.1002/esp.3290160706, 1991.

Gellens, D. and Roulin, E.: Streamflow response of Belgian catchments to IPCC climate change scenarios, J. Hydrol., 210, 242258, doi:10.1016/S0022-1694(98)00192-9, 1998.

Giorgi, F. and Coppola, E.: European climate-change oscillation (ECO), Geophys. Res. Lett., 34, L21703, doi:10.1029/2007GL031223, 2007.

Gouldby, B. and Kingston, G.: Uncertainty and sensitivity analysis method for flood risk analysis, FLOODsite Report Number T024-10-07, HR Wallingford, Wallingford, 2007. 
Hilferink, M. and Rietveld, P.: Land Use Scanner: an integrated GIS model for long term projections of land use in urban and rural areas, J. Geogr. Syst., 1, 155-177, doi:10.1007/s101090050010, 1999.

Klijn, F., Baan, P. J. A., De Bruijn, K. M., and Kwadijk, J.: Overstromingsrisico's in Nederland in een veranderend klimaat. Verwachtingen, schattingen en berekeningen voor het project Nederland Later, Report number Q4290, WL|Delft Hydraulics, Delft, 2007.

Kok, M., Huizinga, H. J., Vrouwenvelder, A. C. W. M., and Barendregt, A.: Standaardmethode 2004. Schade en slachtoffers als gevolg van overstromingen, Report number DWW-2005-005, Rijkswaterstaat, The Netherlands, 2005.

Kron, W.: Flood Risk = Hazard · Values · Vulnerability, Water Int., 30, 58-68, 2005.

Kwadijk, J. and Rotmans, J.: The impact of climate change on the River Rhine: a scenario study, Climatic Change, 30, 397-425, doi:10.1007/BF01093854, 1995.

Leander, R., Buishand, T. A., Van den Hurk, B. J. J. M., and De Wit, M. J. M.: Estimated changes in flood quantiles of the river Meuse from resampling of regional climate model output, J. Hydrol., 351, 331-343, doi:10.1016/j.jhydrol.2007.12.020, 2008.

Messner, F., Pennning-Rowsell, E. C., Green, C., Meyer, V., Tunstall, S. M., and Van der Veen, A.: Evaluating flood damages: guidance and recommendations on principles and methods. FLOODsite Report Number T09-06-01, HR Wallingford, Wallingford, 2007.

Merz, B. and Thieken, A. H.: Flood risk curves and uncertainty bounds, Nat. Hazards, 51, 437-458, doi:10.1007/s11069-0099452-6, 2009.

Merz, B., Thieken, A. H., and Gocht, M.: Flood risk mapping at the local scale: concepts and challenges, in: Flood risk management in Europe-innovation in policy and practice, edited by: Begum, S., Stive, M. J. F., and Hall, J. W., Springer, Dordrecht, 2007.

Merz, B., Kreibich, H., Schwarze, R. and Thieken, A.: Review article "Assessment of economic flood damage", Nat. Hazards Earth Syst. Sci., 10, 1697-1724, doi:10.5194/nhess-10-16972010, 2010a.

Merz, B., Hall, J., Disse, M., and Schumann, A.: Fluvial flood risk management in a changing world, Nat. Hazards Earth Syst. Sci., 10, 509-527, doi:10.5194/nhess-10-509-2010, 2010b.

Meyer, V. and Messner, F.: National Flood Damage Evaluation Methods - a review of applied methods in England, the Netherlands, the Czech Republic and Germany. UFZ-Discussion Papers. UFZ, Leipzig, 2005.

Meyer, V., Haase, D., and Scheuer, S.: Flood risk assessment in European river basins - concept, methods, and challenges exemplified at the Mulde River, Integrated Environmental Assessment and Management, 5, 17-26, doi:10.1897/IEAM_2008031.1, 2009.

Middelkoop, H., Van Asselt, M. B. A., Van 't Klooster, S. A., Van Deursen, W. P. A., Kwadijk, J. C. J., and Buiteveld, H.: Perspectives on flood management in the Rhine and Meuse Rivers, River Res. Appl., 20, 327-342, 2004.

Ministry of Transport, Public Works and Water Management: Flood risks and safety in the Netherlands (Floris). Floris study - full report. Report number DWW-2006-014. Ministry of Transport, Public Works and Water Management, The Hague, 2005.

New, M., Lopez, A., Dessai, S., and Wilby, R.: Challenges in using probabilistic climate change information for impact assessments: an example from the water sector, Philos. T. Roy. Soc. A., 365, 2117-2131, doi:10.1098/rsta.2007.2080, 2007.

Penning-Rowsell, E. C., Fordham, M., Correia, F. N., Gardiner, J., Green, C., Hubert, G., Ketteridge, A.-M., Klaus, J., Parker, D., Peerbolte, B., Pflügner, W., Reitano, B., Rocha, J., Sanchez- Arcilla, A., Saraiva, M. d. G., Schmidtke, R., Torterotot, J.- P., van der Veen, A., Wierstra, E., and Wind, H.: Flood hazard assessment, modelling and management: Results from the EUROflood project, in Floods across Europe: Flood hazard assessment, modelling and management, edited by: Penning-Rowsell, E. C., and Fordham, M., Middlesex University Press, London, 1994.

Penning-Rowsell, E., Viavattene, C., Pardoe, J., Chatterton, J., Parker, D., and Morris, J.: The benefits of flood and coastal risk management: a handbook of assessment techniques -2010 . Flood Hazard Research Centre, London, 2010.

Pfister, L., Humbert, J., and Hoffmann, L.: Recent trends in rainfallrunoff characteristics in the Alzette river basin, Luxembourg, Climatic Change, 45, 323-337, doi:10.1023/A:1005567808533, 2000.

Priestnall, G., Jaafar, J., and Duncan, A.: Extracting urban features from LiDAR-derived digital surface models, Computers, Environment and Urban Systems, 24, 65-78, 2000.

Samuels, P. and Gouldby, B.: Language of Risk - project definitions. FLOODsite Report Number T32-04-01, HR Wallingford, Wallingford, 2005.

te Linde, A. H., Aerts, J. C. J. H., Hurkmans, R. T. W. L., and Eberle, M.: Comparing model performance of two rainfallrunoff models in the Rhine basin using different atmospheric forcing data sets, Hydrol. Earth Syst. Sci., 12, 943-957, doi:10.5194/hess-12-943-2008, 2008.

te Linde, A. H., Bubeck, P., Dekkers, J. E. C., de Moel, H., and Aerts, J. C. J. H.: Future flood risk estimates along the river Rhine, Nat. Hazards Earth Syst. Sci., 11, 459-473, doi:10.5194/nhess-11-459-2011, 2011.

Tu, M.: Assessment of the effects of climate variability and land use change on the hydrology of the Meuse river basin, $\mathrm{Ph}$. D. Thesis, VU University Amsterdam, Amsterdam, and UNESCOIHE, Delft, 2006.

Tu, M., Hall, M. J., De Laat, P. J. M., and De Wit, M. J. M.: Extreme floods in the Meuse river over the past century: aggravated by land-use changes?, Phys. Chem. Earth C, 30, 267-276, doi:10.1016/j.pce.2004.10.001, 2005.

Tunstall, S. M., Johnson, C. L., and Penning Rowsell, E. C.: Flood Hazard Management in England and Wales: From Land Drainage to Flood Risk Management. Proceedings of the World Congress on natural Disaster Mitigation, New Delhi, India, 2004.

Van de Langemheen, W. and Berger, H. E. J.: Hydraulische randvoorwaarden 2001: maatgevende afvoeren Rijn en Maas. RIZA report number 2002.014. Rijksinstituut voor Integraal Zoetwaterbeheer en Afvalwaterbehandeling, Arnhem, 2001.

Van den Hurk, B. J. J. M., Klein Tank, A. M. G., Lenderink, G., Van Ulden, A., Van Oldenborgh, G. J., Katsman, C., Van den Brink, H., Keller, F., Bessembinder, J., Burgers, G., Komen, G., Hazeleger, W., and Drijfhout, S.: New climate change scenarios for the Netherlands, Water Sci. Technol., 56, 27-33, 2007.

Van der Meulen, M. J., Rijnveld, M., Gerrits, L. M., Joziasse, J., Van Heijst, M. W. I. M., and Gruijters, S. H. H. L.: Handling Sediments in Dutch River Management: The Planning Stage of 
the Maaswerken River Widening Project, J. Soil. Sediment., 6, 163-172, 2006.

Van der Sande, C. J., De Jong, S. M., and De Roo, A. P. J.: A segmentation and classification approach of IKONOS-2 imagery for land cover mapping to assist flood risk and flood damage assessment, Int. J. Appl. Earth Obs., 4, 217-229, doi:10.1016/S03032434(03)00003-5, 2003.

Van Deursen, W. P. A. and Middelkoop, H.: Development of flood management strategies for the Rhine and Meuse basins in the context of integrated river management. Executive summary of the IRMA-SPONGE Project 2, in: Towards Sustainable Flood Risk Management in the Rhine and Meuse River Basins, edited by: Hooijer, A., and Van Os, A., NCR, Delft, 2002.

Van Looy, K., Meire, P., and Wasson, J-G.: Including riparian vegetation in the definition of morphologic reference conditions for large rivers: a case study for Europe's Western Plains, Environ. Manage., 41, 625-639, doi: 10.1007/s00267-008-9083-9, 2008.

Vanneuveille, W. and Holvoet, K.: AMICE: sub report 1 - Belgian scenarios for the Meuse. Version 2_0. WL Adviezen 710_14. Flanders Hydraulics Research and Deltares, Antwerp, 2009.

van Pelt, S. C., Kabat, P., ter Maat, H. W., van den Hurk, B. J. J. M., and Weerts, A. H.: Discharge simulations performed with a hydrological model using bias corrected regional climate model input, Hydrol. Earth Syst. Sci., 13, 2387-2397, doi:10.5194/hess13-2387-2009, 2009.
Vis, M., Klijn, F., De Bruijn, K. M., and Van Buuren, M.: Resilience strategies for flood risk management in the Netherlands, International Journal of River Basin Management, 1, 33-40, 2003.

Ward, P. J., Aerts, J. C. J. H., De Moel, H., and Renssen, H.: Verification of a coupled climate-hydrological model against Holocene palaeohydrological records, Global Planet. Change, 57, 283300, doi:10.1016/j.gloplacha.2006.12.002, 2007.

Ward, P. J., Renssen, H., Aerts, J. C. J. H., van Balen, R. T., and Vandenberghe, J.: Strong increases in flood frequency and discharge of the River Meuse over the late Holocene: impacts of long-term anthropogenic land use change and climate variability, Hydrol. Earth Syst. Sci., 12, 159-175, doi:10.5194/hess-12-1592008, 2008.

Ward, P. J., Renssen, H., Aerts, J. C. J. H., and Verburg, P. H.: Sensitivity of discharge and flood frequency to 21 st Century and late Holocene changes in climate and land use (River Meuse, northwest Europe), Climatic Change, 106, 179-202, doi:10.1007/s10584-010-9926-2, 2011.

Wind, H. G., Nieron, T. M., De Blois, C. J., and De Kok, J. L.: Analysis of flood damages from the 1993 and 1995 Meuse floods, Water Resour. Res., 35, 3459-3465, 1999.

Woodhead, S., Asselman, N., Zech, Y., Soares-Frazão, S., Bates, P., and Kortenhaus, A.: Evaluation of inundation models. Report number T08-07-01. WL|Delft Hydraulics, Delft, 2007.

Wouters, K.: Veiligheid Nederland in kaart globale schadeberekening. Rijkswaterstaat, Delft, 2005. 